\title{
Geological Heritage of Syros Island, Cyclades Complex, Greece: An Assessment and Geotourism Perspectives
}

\author{
Hara Drinia ${ }^{1, *(\mathbb{D})}$, Theodora Tsipra ${ }^{1}$, George Panagiaris ${ }^{2}$, Marios Patsoules ${ }^{3}$, Christina Papantoniou ${ }^{1}$ \\ and Andreas Magganas ${ }^{1}$ (D) \\ 1 Department of Geology and Geoenvironment, National and Kapodistrian University of Athens, \\ Panepistimiopolis, 15784 Athens, Greece; ttsipra@geol.uoa.gr (T.T.); papantoniouxrist@gmail.com (C.P.); \\ amagganas@geol.uoa.gr (A.M.) \\ 2 Department of Conservation of Antiquities and Works of Art, University of West Attica, \\ 11521 Athens, Greece; gpanag@uniwa.gr \\ 3 Advisory Board of Syros Municipality for the Development of the Cyclades Geopark, \\ 84100 Hermoupolis, Greece; mpatsoules@hotmail.com \\ * Correspondence: cntrinia@geol.uoa.gr
}

Citation: Drinia, H.; Tsipra, T.; Panagiaris, G.; Patsoules, M.; Papantoniou, C.; Magganas, A. Geological Heritage of Syros Island, Cyclades Complex, Greece: An Assessment and Geotourism Perspectives. Geosciences 2021, 11, 138. https://doi.org/10.3390/ geosciences 11030138

\section{Academic Editors:}

Jesus Martinez-Frias and Teresa Brzezińska-Wójcik

Received: 14 January 2021

Accepted: 12 March 2021

Published: 16 March 2021

Publisher's Note: MDPI stays neutral with regard to jurisdictional claims in published maps and institutional affiliations.

Copyright: (c) 2021 by the authors. Licensee MDPI, Basel, Switzerland. This article is an open access article distributed under the terms and conditions of the Creative Commons Attribution (CC BY) license (https:// creativecommons.org/licenses/by/ $4.0 /)$.

\begin{abstract}
Syros Island, Cyclades complex, central Aegean Sea, Greece, is a prime locality for the study of processes active in deep levels of orogens and is world famous for its exceptionally well preserved glaucophane schist-to eclogite-facies lithologies. Glaucophane schists and eclogites are witnesses of one of the fundamental tectonic processes operating on planet Earth. Results of geological research on Syros have contributed a lot to our present understanding of why and how these processes work that make oceans disappear, how mountain ranges can start to form, how magma chambers form to feed volcanoes, how subduction mechanisms can trigger earthquakes and lead to tsunamis, and a series of other spectacular or very impressive phenomena which have been observed and studied throughout the earth's window offered in that particular place of the world. The description, interpretation, and evaluation of the important geological heritage of Syros, in combination with a SWOT analysis, showed the geotourism potential of the region. The results of this paper are intended to constitute a valuable tool for enhancing and raising awareness of the geological heritage of the island of Syros, regarding to the added value activities to be developed on a sustainable basis.
\end{abstract}

Keywords: geosite; geotourism; Syros island; metamorphic rocks; subduction zone; sustainable development

\section{Introduction}

Greece, due to its position along the convergence zone between two tectonic plates (African and Aegean microplate), presents a variety of geoforms and formations worthy of conservation for world science and research. For this reason, Greece is well known to the world geological community as a "natural geological laboratory", which provides valuable information concerning global geodynamic processes as it is characterized by intense earthquake activity, volcanoes, variable sediment processes, coastal dynamics, and others. At the same time, Greece represents a great geo-museum hosting "moments" of the complicated evolution of our planet, from Proterozoic until today. These "moments" are represented by the geosites and geomorphosites which, according to Reynard [1], are "portions of the geosphere that present a particular importance for the comprehension of Earth history." The Meteora, the Olympus Mountain, the Samaria Gorge in Crete, the ancient Lavrion mines in the Sounion National Park, the Petrified Forest of Lesvos, the Vicos and Aoos Gorges in Epirus, the Diros Caves in Peloponnesus, the Santorini Volcanic Caldera, the Prespes Lakes in West Macedonia, the Falakron Mountain-Aggitis Karstic System in East Macedonia, are some of the most significant geosites which constitute well-known, legally protected and developed tourist attractions with thousands of visitors each year [2]. 
According to Fassoulas and Zouros [3], a geosite must be related to the surrounding area and its cultural heritage and should be of unparalleled scientific, aesthetic, cultural, and ecological value. However, very often, the geosites are irreparably destroyed by ignorance. The protection of geosites in Greece, considering their intrinsic value to the natural environment, is primarily related to the conservation of biodiversity and ecosystems or to the protection of cultural sites. Geosites have therefore not gained autonomous recognition as important elements for protection and management [2].

Geoparks are areas which contain a distinct geological heritage. They are demarcated areas, well organized for the preservation of territorial ecosystems and promotion of geoheritage conservation, geo-education and sustainable regional growth using geotourism products [4]. Significant geosites are recognized worldwide through the activity of geoparks and benefit from the exchange of information, skills, experience and staff between geoparks. In recent years, geoparks have introduced a number of activities, following the provisions of their management strategy, aimed at further improving their facilities, services, activities and promotion. In this way, they support local economic and cultural growth of the areas $[5,6]$. Greece hosts five of UNESCO's global geoparks: the Petrified Forest on the island of Lesvos, the Vikos-Aoos National Park in Epirus, the Chelmos-Vouraikos National Park in the Peloponnese, the Psiloritis National Park on Crete, and the Sitia Nature Park on Crete.

In recent years, the involvement of the Greek scientific community with geotopes has intensified, with the result that the research is expanded and new aspects are analyzed that highlight the educational value of geotopes [7-10] as well as their connection with Greek mythology [11,12].

Moreover, nowadays, Greece faces the "new" challenge of Geotourism, not only because it can redistribute the tourism product of the country in areas that until now are not tourism destinations, but mainly because it can provoke a new quality tourism flow. Geotourism constitutes a very good tool for highlighting and developing an area and should be used properly and especially prudently. The usual forms of geotourism in Greece are cave tourism (only in tourist caves) and spa tourism. Greek geotopes, however, can support other activities, targeting a wide range of citizens.

The present paper focuses on the promotion of the geological wealth of the island of Syros, central Aegean Sea, with the aim of integrating the island in the international environment of Geoparks, in the near future. For the scientific community, Syros is considered a geological museum that combines research, geological, archaeological and cultural interest, and needs to be preserved and highlighted, as it constitutes a significant and highly representative location to analyze the structure of a subduction zone, that is a major component of the earth lithosphere. While the geological evidence is spectacularly visible-and easily accessible - on Syros, and numerous geology students and earth scientists keep visiting, and a significant number of research articles have been written on Syros geology, the island's significance is essentially unknown to the public. The promotion and connection of the geological heritage of Syros in the already provided tourism product will attract people from all over the world with different kind of interests and will make it known to alternative tourists.

\section{Study Area}

Syros Island belongs to the Cycladic Islands Complex, which forms the so-called Cycladic plateau in the central Aegean Sea (Greece) (Figure 1). The archipelago of the Cyclades, according to historical sources, is named after the circle formed by the islands around the sacred center of Dilos. However, it is a group of islands that stretch away from mainland Greece southeastwards and are nothing but the tops of sunken mountains which are bordered to the west by Evvoia and the peninsula of Attica. The Cycladic archipelago is located between the parallels $38^{\circ} 05^{\prime}$ and $36^{\circ} 20^{\prime}$ (north latitude) and meridians 24th and 26th (east longitude) and is bounded to the west by the Myrtoan Sea, to the east by Ikarian 
and Southern Aegean Seas, to the south by the Cretan Sea and to the north by the sea of the central Aegean.

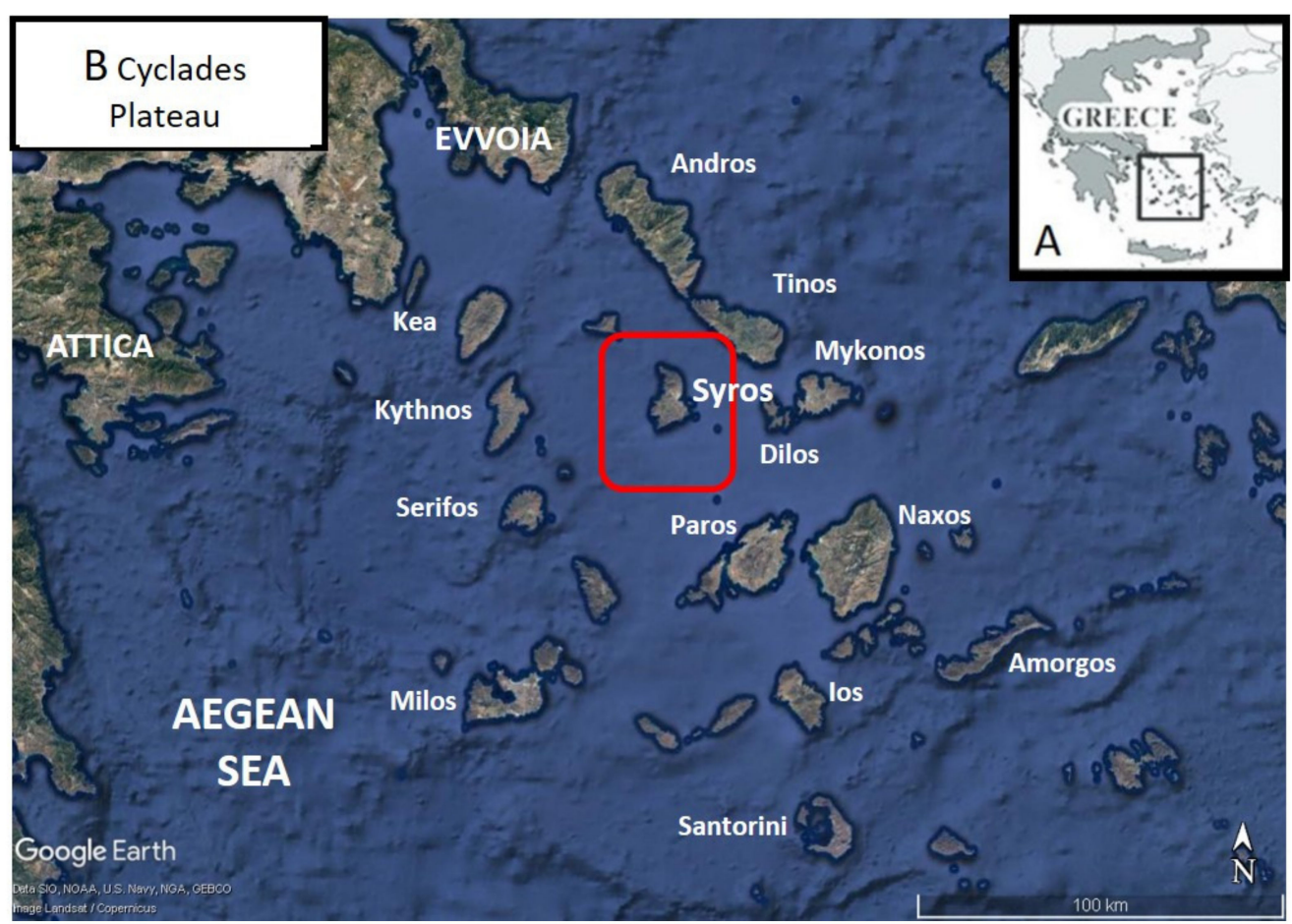

Figure 1. (A). Sketch map of Greece indicating the location of Cyclades Plateau, (B). Satellite photo of the Cyclades plateau, indicating the location of Syros island.

The Cycladic plateau is composed of 20 large islands, the largest being Naxos $\left(430 \mathrm{~km}^{2}\right)$, followed by Andros $\left(380 \mathrm{~km}^{2}\right)$ and Tinos $\left(196.5 \mathrm{~km}^{2}\right)$, all situated in the eastern part of the Cycladic plateau [13]. Four islands are much smaller and are located along the western edge of the plateau (Kea, Kythnos, Serifos, and Sifnos). Syros, Paros, Ios, and Mykonos are between these two island groups. Milos, Santorini, and Amorgos are considered peripheral extensions of the plateau and are clustered along the southern edge of it (Figure 1).

Syros belongs to the administrative Region of the South Aegean which is a region with high potential in geotopes and geodiversity. The volcanic complex of Santorini is ranked as a global geological monument. The Kleftiko and the Sarakiniko of Milos, the volcanic complex of Nisyros, and the Antiparos cave are geological monuments of international interest. In addition, there are many geological sites which are of tourism interest only at regional-local level. According to Skentos [14], the geotopes are placed as a whole, in areas with intense relief, mostly connected to the coastal environment. They have a high concentration density in areas associated with volcanic activity both during the Upper Miocene and during the Pliocene-present (Milos, Santorini, and Nisyros).

Syros Island, located in the central part of the Cyclades, is primarily made up of the Cycladic Blueschist Unit (CBU), one of the world's best-case studies of a fossilized subduction system, and is known for its outstanding preservation of metamorphic HP-LT (High Pressure-Low Temperature) rocks such as eclogites and blueschists. Hence, many studies focusing on petrology, structure, and geochronology, are being carried out in this island, in order to unravel the tectonometamorphic evolution of the CBU subduction complex (e.g., [15-27]).

\section{Geological Setting}

The island of Syros is in the Aegean Sea and specifically in the center of the Cycladic archipelago. The Aegean region (eastern Mediterranean Sea) has experienced a tectonic and metamorphic transformation established by two distinct stages. Initially, the collision 
of Africa-Eurasia plates from the late Cretaceous to the Eocene contributed to the formation of the Hellenides-Taurides chain, which consists of a pile of oceanic and continental nappes attributed to Apulia [28-30]. Subsequently, the kinematics in the upper plates of the Mediterranean subduction zone have been mainly affected by the southward retreat of the African slab since $35 \mathrm{Ma}$ [31-33], Jolivet and Brun [28] accounted for the expansion of the back-arc zone (Figure 2). The archipelago of the Cyclades is the result of the collapse of the Hellenides-Taurides belt generated by this retreating subduction that altered the kinematic boundary conditions in the back-arc area from compressional to extensional [34,35].

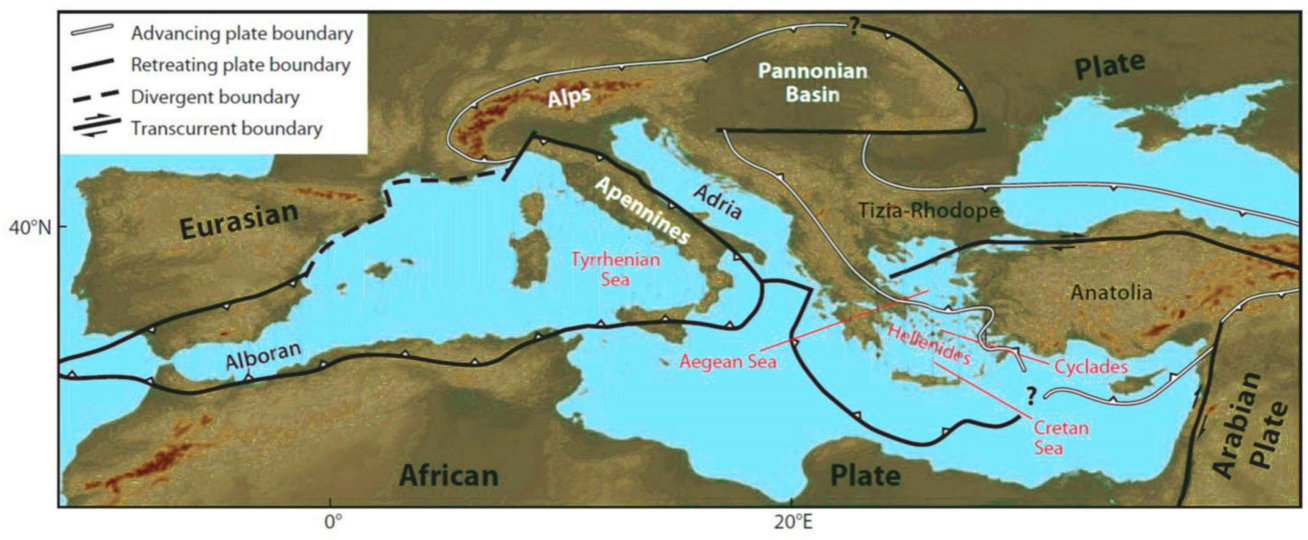

Figure 2. Simplified tectonic map of the Mediterranean plate-boundary zone showing the three major plates (Eurasian, African, and Arabian) shown, and the microplates between them. The Hellenides, the Aegean and Cretan Seas, and the Cyclades are shown [29].

From a geological viewpoint, Syros island is part of the Attic-Cycladic Crystalline Belt (ACCB), (Figure 3). This belt is characterized by the occurrence of four major tectonic units, which are from top to bottom: the Upper Unit (UU), the Cycladic Blueschist Unit (CBU), the Cycladic Basement Unit, and the Basal Unit.

The island of Syros incorporates the two uppermost structural units of the ACCB, separated between them by low-angle faults [36-38] (Figure 4). The Upper Unit (known also as Vari Unit) is mostly exposed in the SE part of the island. It is primarily composed of a diverse sequence of Late Cretaceous epidote-amphibolite-facies orthogneisses originated from Triassic granitoids, as well as schists and phyllites of greenschist facies, which enclose few serpentinite blocks $[16,24]$. The underlying Cycladic Blueschist Unit, consists of a preAlpidic basement of micaschists and gneisses superimposed by metamorphosed volcanosedimentary thrust sheets, which comprise alternating sequences of marble, micaschist and metabasites. Recent field observations together with structural and petrological findings on the island of Syros allows the subdivision of the CBU into three subunits, from top to base, the Kampos, Chroussa, and Posidonia Subunits, separated by major ductile shear zones, all structurally resting below the Vari Unit, showing no signs of HP [19]. In northern and central Syros dominant are the two tectonic subunits at kilometer scale: the Chroussa Subunit composed mostly of light marble and dark glaucophane schists and the Kampos "mélange" zone comprising mainly eclogites and serpentinites. In opposite Posidonia Subunit, which is mostly located at the southwestern part of the island, comprises the felsic gneiss of Komito, albitic micaschists, some marbles and few metabasites.

Syros Island is mostly known all over the geological world, among many others, for the occurrence of HP-LT parageneses in the CBU, offering one of the best examples to study in situ and unravel the tectonometamorphic evolution of a subduction system. Two phases of Tertiary metamorphism were registered in the CBU. The subduction of the Apulian microplate under the Eurasian continent [39], fueled the first metamorphic event at eclogite-to-blueschist-facies conditions ( $\mathrm{T}=500-550^{\circ} \mathrm{C}, \mathrm{P}=15-20 \mathrm{kbar}$; e.g., [23,26,40-42]), which probably culminated at Lower Eocene (ca. 53-49 Ma) ([18,25]). The retrograde 
second metamorphic event, which was of greenschist-to amphibolite-facies, was dated at

25-21 Ma [43]. Finally, the CBU exhumed between 12 and 8 Ma ago [24,44].
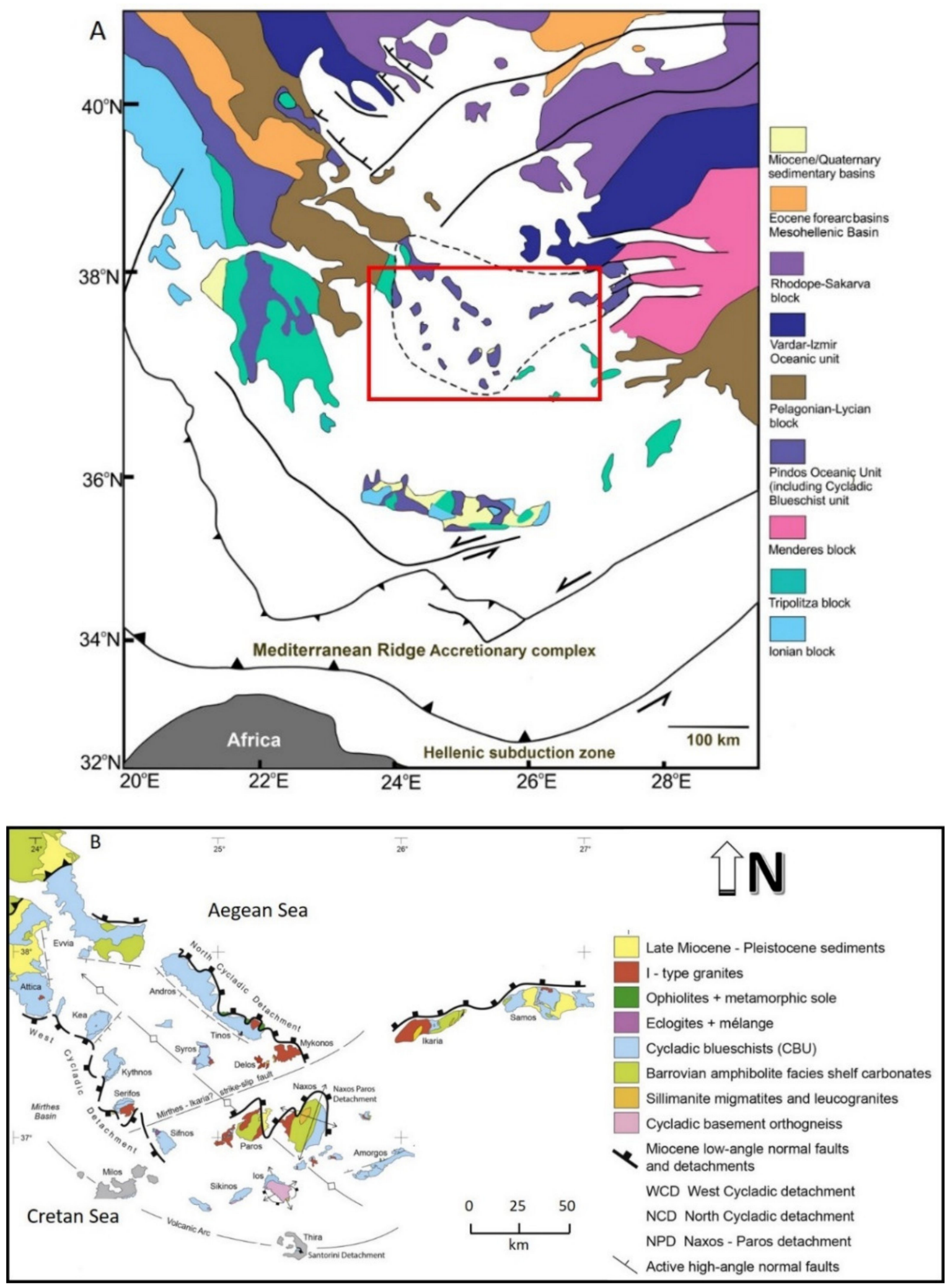

Figure 3. (A). A simplified tectonic map showing the major tectonic zones above the Hellenic subduction zone of the Aegean region (modified after [28,29]), (B). Simplified geological map of the Attic-Cycladic Crystalline Belt, showing the major tectonic units [28] (modified). 

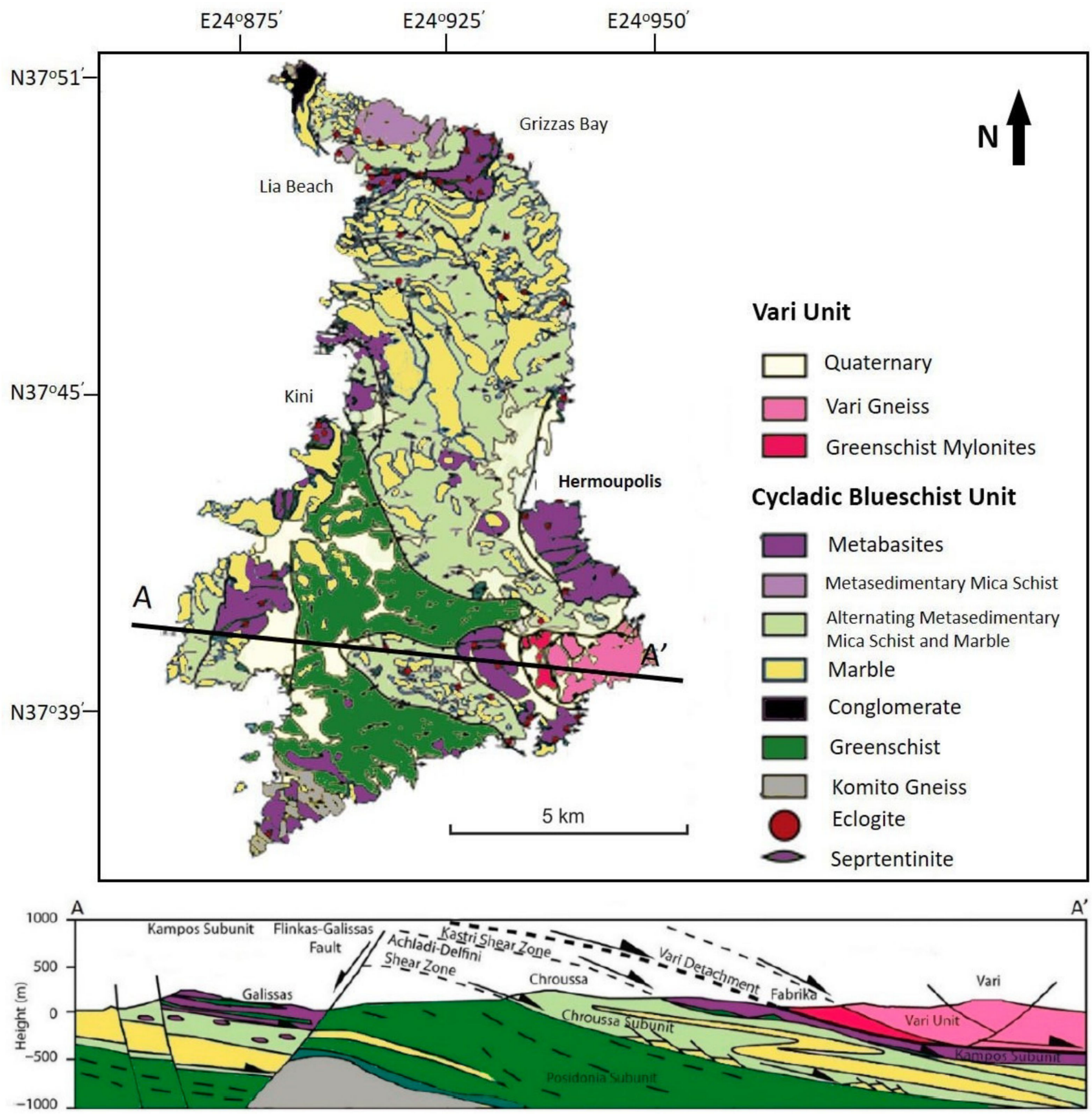

Figure 4. Geological map and cross-section of Syros island, simplified after $[16,17,20,22]$ and our own observations.

\section{Methodology}

The methodological scheme followed in this research includes five successive stages (Figure 5). The first stage concerns the characterization of the area regarding the geological setting and the archaeological-cultural context. For this reason, many of the results of previous research and studies concerning the geological setting of Syros Island were selected and incorporated in this paper. Most of the studies are focusing on geological-geomorphological field descriptions and mapping, as well as morphometric and morphotectonic studies concentrating on the geological characteristics and geomorphological landforms of this area (e.g., $[19,20,22,24])$. The main and most exciting findings were chosen from these studies and additional field observations were carried out to be presented to a wide public. 


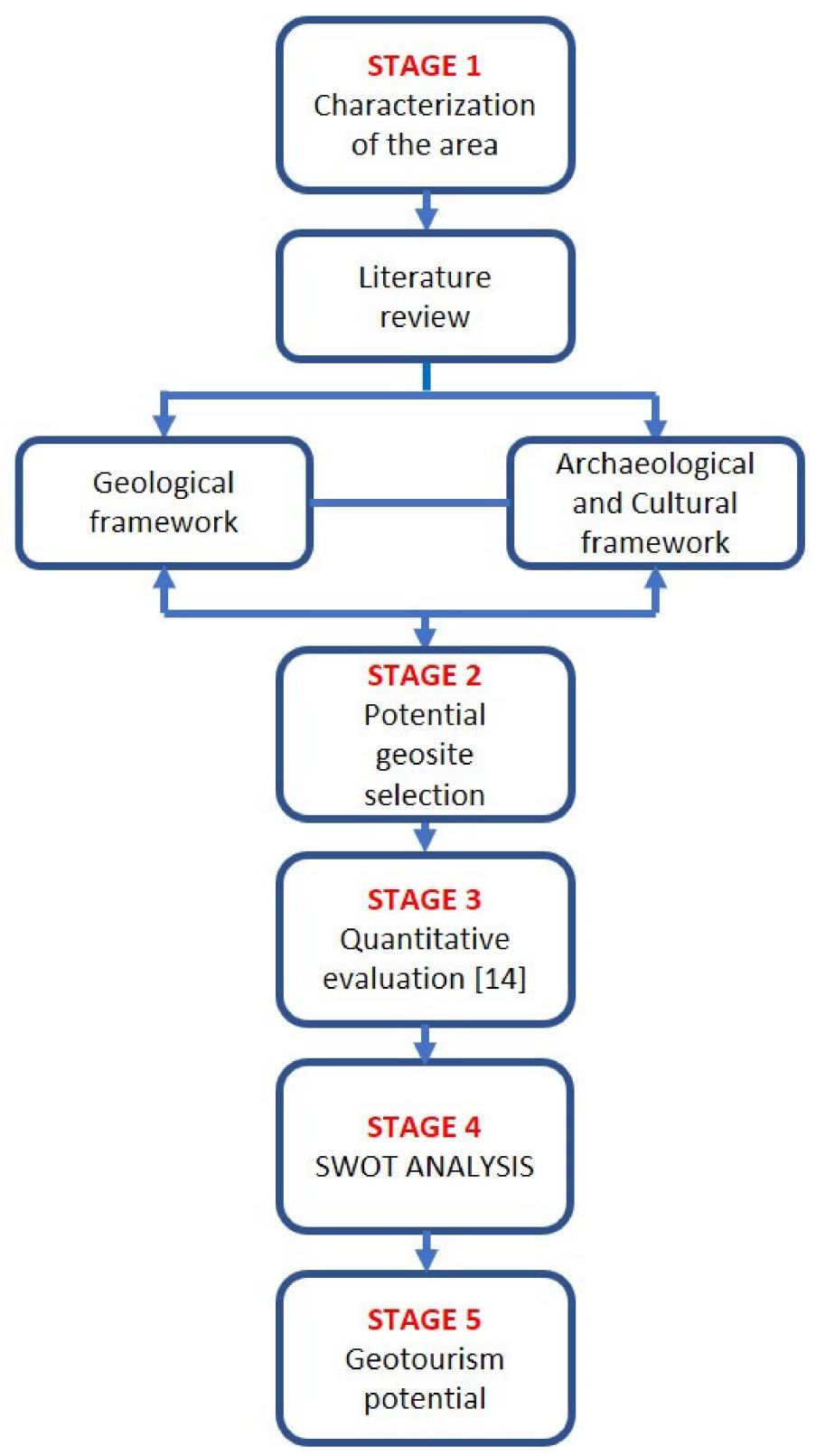

Figure 5. Methodology flow chart followed in this paper.

The geological and archaeological literature review of the study area, revealed a number of potential geosites. In the second stage of the research, only one geosite (the most widely known in the scientific community) was selected in order to document the geotourism potential of the island. Future research will allow the creation of an inventory containing all the geological interest sites of the island.

The quantitative assessment of the geotope (stage 3) constitutes the foundation in the decision-making framework for the implementation of geotourism. The simple evaluation scheme of Skentos [14] is used to determine the current status of the geosite.

Although evaluation is adequate for the recognition of important geosites, there is a need for additional data to make available access decisions. For this purpose, a SWOT analysis (stage 4) should be generated based on evaluation data, which clearly determines the strengths and weaknesses, opportunities, and threats. In our research, a basic SWOT analysis was applied (e.g., [45-48]), with the participation of a small number (50) of representatives of the public and private sectors, as well as of the general public, with the 
objective of gathering some preliminary opinions in order to consider and further evaluate the geotourism potential of the area (stage 5).

Concerning the geological heritage of the island, its scientific value was appreciated by highlighting its importance in the contribution to knowledge advance. At the same time its academic value, translated as the ease with which this knowledge is communicated to society, was valorized.

\section{Results}

\subsection{Qualitative Evaluation of the Geological Heritage of Syros}

The special petrological and tectonic history of Syros is highlighted through the extraordinary, perhaps unique, preservation and easily accessible mineral parageneses and tectonic structures on a very soft relief of the island. These mineral parageneses are related to a geotectonic environment, that of subduction, which is critical and essential to understanding how the planet works and evolved.

On our planet, the conditions suitable for these mineral parageneses to grow, are limited to special tectonic environments, notably subduction zones. Actually, research geologists from all over the world keep coming to Syros for their studies because the rocks exposed on the island were formed in such a subduction zone. Therefore, the area is suitable for geoconservation and geo-education.

Indeed, in Northern Syros, the Chroussa and Kampos subunits offer insight into how a deep subduction complex was assembled and then carried up to the Earth's surface (Figures 4 and 6). In both subunits, strong deformation is clearly visible, at all scales ( $\mathrm{cm}$ to $\mathrm{km}$ ), including folds and fractures within rocks and between different layers or bodies of rock. Strong deformation reflects several important stages in the evolution of Syros, essentially starting 55 million years ago, when oceanic crust (parts of the Pindos ocean) began to be subducted beneath a continental block (Adria). Over a period of at least 5 million years, a tectonic channel was assembled by thrusting and strong folding. This is when, at depths of up to $50 \mathrm{~km}$, the Kampos "mélange" started to form at very high pressures (ca. 16,000 times normal pressure). As the northward movement of Africa slowed down, this allowed the mélange to be exhumed between 50 and $35 \mathrm{Ma}$ ago. As a result of these giant movements, the Kampos shear zone ended up being squeezed in between two tectonic slices of the Chroussa unit. The contact surfaces, along which the tectonic units moved into their present position, are precisely known on Syros because of the detailed geological maps produced over half a century of study. Deformation features, such as folded rocks and faults in between kilometer-size masses of rocks are well visible. Based on numerous geological investigations, the assembly of the tectonic units has been reconstructed, and the evolution of the rocks present on Syros can now be understood in some detail. However, results of the studies are continually being debated, and many questions remain open, which is why international geological research continues in order to resolve these.

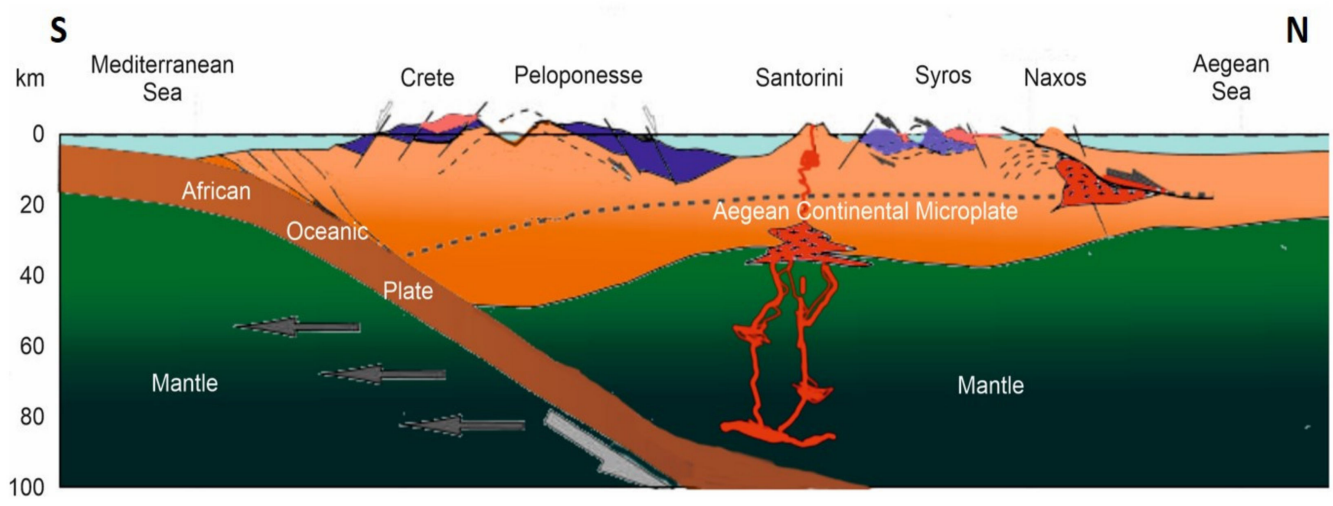

Figure 6. Schematic reconstruction of the northward dipping Hellenic Subduction system. 
Consequently, Syros, possibly is a unique "geological laboratory" around the world, in which are being studied processes with the orogenesis at the Earth's crust, attributable to the collision between two lithospheric plates, with the one subducting under the other. More precisely, the uniqueness lies in the fact that the submergence of outcropping lithological units to the mantle depth of around (40-70 km or down to $100 \mathrm{~km}$ ) and their uplifting again on the surface, at geological period of relatively recent time. This round-trip of the rock formations, reflected exceptionally in Syros with the creation and favorably display well-preserved rare rock types. For this reason, a great number of petrological, geochronological and structural studies have focused on the rocks of this island, resulting in various interpretations mainly concerning (1) the overall CBU geometry, (2) metamorphic peak conditions, (3) the position of significant tectonic contacts, and 4) the geochemical processes taken place.

In view of their exceptional petrological characteristics, there are many interesting outcrops, scattered throughout the island, though mostly occur in its northern part (Figure 4). For example, in the coastal outcrop in the SW of Grizzas Bay igneous-textured metagabbro, meta-plagiogranite and megalithic ophiolitic breccia are observed, at the northern side of Hermoupolis sphene and tourmaline-bearing reaction zones (blackwalls) occur, in San Michalis (Kampos) and on the way to Lia Beach jadeitite is found, which by the way is considered the largest known source of jadeite ancient artifacts in the Aegean, and one of the largest in the Mediterranean area [49]. Outcrops which exhibit the exceptional petrological diversity of the HP-LT metamorphic rocks, can be considered also those occur in between San Michalis and Lia Beach. These outcrops include firstly two impressive dark colored monolithic rock structures. The biggest monolith, which has been named by the locals "aerolithos" - that means rock coming from the air(!)—is an eclogitic large block partially enveloped by relatively thin blueschist layers (Figure $7 \mathrm{a}, \mathrm{c}$ ) - a rock which, as written before, was originated from the great depth of about $80 \mathrm{~km}$ within the earth. Other very interesting outcrops in Kampos-Lia beach area also include phengite glaucophane schists bearing emerald like and highly aesthetic pseudomorphs of lawsonite crystals, schists bearing large garnet porphyroblasts (Figure 7e) and light green serpentinitic rocks. Moreover, in northern Syros outcrops of rare impure marbles bearing pseudomorphic aragonite needles and glaucophane exist, as well as dark gray graphite schists. In the Kini bay the outcrops comprising mainly blueschists, eclogites, coarse grained green Mg-rich and blackish Fe-rich metagabbros (Figure 7f,g), as well as the dark green epidote-rich sandy beach, are quite remarkable. It is notable that Mg-gabbros of Kini contain large crystals of green omphacitea mineral named from the ancient Greek word ó $\mu \varphi \alpha \xi$ (omphax = unripe grape) in allusion to its typical green color-and plagioclase [50], while Kini is also known as type locality of another important and characteristic blue mineral of HP-LT metamorphism, the glau-

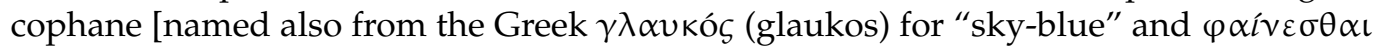
(phainestai) "to appear", in reference to its color], which firstly discovered therein by Hausman at 1845 [51]. Other places with outcrops deserved to be visited are found in the broader area of Airport, where one can observe striking vivid blue colored schists and the rarely preserved phenomenon of felsic and mafic magma mixing (Figure $7 \mathrm{c}, \mathrm{d}$ ), the Vari area exhibiting interesting tectonic structures as evidence for exhumation of the southern Syros, and the Komito area where an orthogneiss, dated as the oldest rock of Syros, occur.

By these above-mentioned reasons, we consider the outcrops/areas of Syros described are places having an undoubted petrological and generally great earth science interest. They can be easily characterized as places of substantial geological heritage that is worth protecting from imminent threat for destruction for various economic or other uses. 

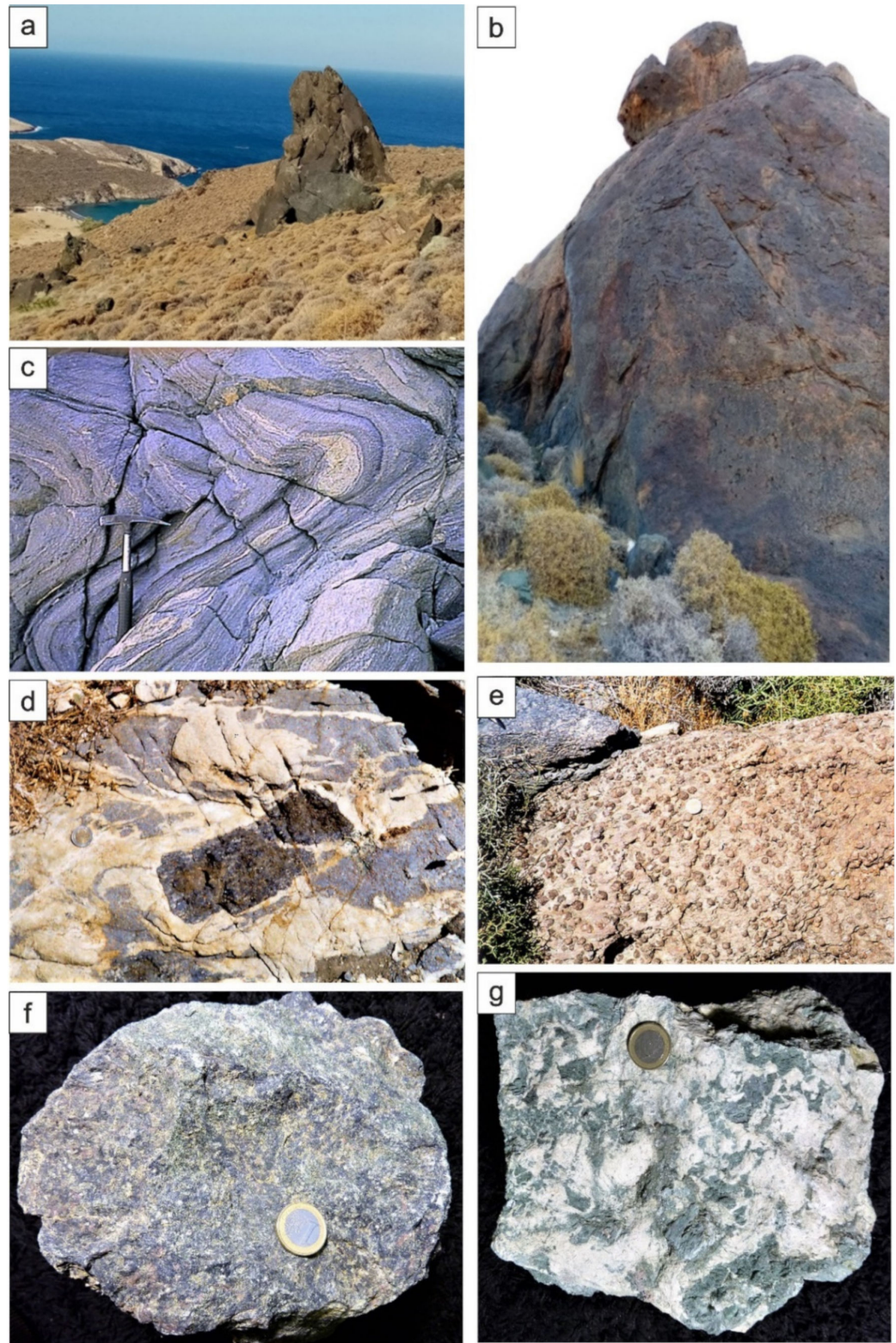

Figure 7. (a). Eclogitic monolith locally known as "aerolithos", from near to Lia Beach, (b). Close up of the monolith depicting the blueschist envelope, (c). Vivid colored blueschist folded intensely, Airport area, (d). Felsic and mafic magma mixing engulfing a rectangular eclogitic fragment, Airport area, (e). Fine grained pelite with large garnet porphyroclasts, Kampos, (f). Retrograded eclogite from Kini, (g). Mg-rich omphacitic metagabbro from Kini.

\subsection{Quantitative Evaluation of Geotourism Potential}

Successful and efficient management of geological heritage, whether geotope or geopark, should be focused on its contribution to local, national, or global geodiversity conservation. The value of geological heritage to science and contemporary culture through a comparable and quantitative assessment method must be demonstrated in order to expose this contribution [52]. Therefore, the importance of geological heritage must be quantified and recorded and geodiversity assessed using a standardized approach appropriate to geoscientists and the broader environmental community. The application of this standardized approach, which will be a powerful and reliable assessment process, can increase the effectiveness of geodiversity protection and geotourism, which is the tool for highlighting the geological heritage. 
According to Archontikis [53], the purpose of a quantitative assessment is to minimize the subjectivity associated with any evaluation process.

In the last decade, research on the numerical evaluation of geotopes has been growing, but a widely accepted approach has not yet been established in the geoscientific community. The main problem is that a different emphasis on evaluation criteria is given each time, depending on the interests and views of researchers, with the result that objectivity is not ensured. Quantitative approaches are usually focused on various standards and relevant metrics to which different scores or parameters can be assigned [52,54-65].

In this study, the adopted evaluation method is the one of Skentos [14] and is based on 13 criteria: Geological History, Representativeness, Geodiversity, Rarity, Conservation, Education, History-Archeology, Religion, Visibility, Landscape Differentiation, Accessibility, Tourist infrastructure, and Ecological value, rating from 1 (lowest value) to 5 (highest value) for each criterion (Table 1). For the quantitative evaluation, Skentos [14] grouped the above criteria into: Geology, Culture, Aesthetics, Tourism, and Ecology. The quantification of data from all the criteria set for the assessment of geotopes led to the comparison and correlation of geotopes. For each registered geotope, there is a specific value (Total Score = Sum of rating criteria/Number of used criteria), indicative of the value of the geotope, which is related to its final classification position. If Total Score $>3.5$, then the Geotope is of Global interest. In case where 3.5 > Total Score > 3.0, then it is a Geotope of National interest and finally, if Total Score $<3$, then it is a Geotope that is of Local interest only.

Table 1. Quantitative grading of the criteria $[14,53]$.

\begin{tabular}{|c|c|c|c|c|c|}
\hline Criteria & 1 & 2 & 3 & 4 & 5 \\
\hline $\begin{array}{l}\text { Geological } \\
\text { History }\end{array}$ & $\begin{array}{l}\text { Small participation } \\
\text { at local level }\end{array}$ & $\begin{array}{c}\text { Moderate } \\
\text { participation in } \\
\text { local level }\end{array}$ & $\begin{array}{l}\text { Great participation } \\
\text { in local level }\end{array}$ & $\begin{array}{c}\text { Moderate } \\
\text { participation at } \\
\text { regional level }\end{array}$ & $\begin{array}{l}\text { Great participation } \\
\text { at regional level }\end{array}$ \\
\hline Representativeness & Not at all & Low & Medium & High & Unique \\
\hline Geodiversity & 1 & $<3$ & $<5$ & $<10$ & $>10$ \\
\hline Rarity & $>20$ & $>10$ & $>5$ & $>2$ & Unique \\
\hline Conservation & Totally damaged & Low & Medium & High & Intact \\
\hline Education & Not at all & - & Medium & - & High \\
\hline $\begin{array}{c}\text { History- } \\
\text { Archaeology }\end{array}$ & Not at all & $\begin{array}{l}\text { Existing-Low } \\
\text { importance }\end{array}$ & Minor importance & $\begin{array}{c}\text { Moderate } \\
\text { importance }\end{array}$ & $\begin{array}{c}\text { Great importance- } \\
\text { Geohistoric } \\
\text { position }\end{array}$ \\
\hline Religion & Not at all & $\begin{array}{l}\text { Existing-Low } \\
\text { importance }\end{array}$ & Minor importance & $\begin{array}{l}\text { Moderate } \\
\text { importance }\end{array}$ & $\begin{array}{c}\text { Great importance- } \\
\text { Geohistoric } \\
\text { position }\end{array}$ \\
\hline Visibility & 1 & 2 & 3 & 4 & $>4$ \\
\hline $\begin{array}{c}\text { Landscape } \\
\text { Differentiation }\end{array}$ & Not at all & Low & Medium & High & Very high \\
\hline Accessibility & Not accessible & Low & Medium & High & Very high \\
\hline $\begin{array}{c}\text { Tourist } \\
\text { Infrastructure }\end{array}$ & Not at all & Low & Medium & - & High \\
\hline Ecological Value & Not at all & - & Medium & - & High \\
\hline
\end{tabular}

In this research, the assessment process focused on the most impressive, to the general public, geosite which is the "Aerolithos" Eclogites. The results of the evaluation are shown in Table 2. The assessment process of the proposed geosite is attempted after having gathered all the necessary data from the literature and fieldwork. The average of all these values outlines the geotope's final classification and it is concluded that the "Aerolithos" Eclogites in Northern Syros belongs to the category "Geotopes of Global Interest". 
Table 2. Geosite evaluation. The numerical expression of the group indicators is given, followed by the values for each indicator.

\begin{tabular}{|c|c|c|}
\hline \multicolumn{2}{|c|}{ Criteria } & Score \\
\hline \multirow{6}{*}{ Geology } & Geological History & 5 \\
\hline & Representativeness & 5 \\
\hline & Geodiversity & 3 \\
\hline & Rarity & 4 \\
\hline & Conservation & 5 \\
\hline & Education & 5 \\
\hline \multirow{2}{*}{ Culture } & History-Archeology & 4 \\
\hline & Religion & 1 \\
\hline \multirow{2}{*}{ Aesthetics } & Visibility & 5 \\
\hline & Landscape Differentiation & 5 \\
\hline \multirow{2}{*}{ Tourism } & Accessibility & 3 \\
\hline & Tourist infrastructure & 4 \\
\hline Ecology & Ecological value & 3 \\
\hline Total & & 18.5 \\
\hline Average & & 3.7 \\
\hline
\end{tabular}

The results of the assessment indicate that the geosite of Northern Syros' Eclogites has great potential to become a popular geotourism destination. The first two group indicators describe the classic ABC (Abiotic (geology and climate)-Biotic (flora and fauna)Culture (lifestyle of people)) approach of Dowling [66] which must be accompanied by another set of objective parameters, named "aesthetics". Indeed, there are geological sites of great scientific value which are short of interest to the general public due to low aesthetic value. It is the beauty of geosites that makes people want to understand how these places were made.

\subsection{SWOT Analysis}

A preliminary survey was conducted on 50 participants to assess the real geotourism potential of geological heritage growth on Syros Island, summarizing and comparing strengths, weaknesses, opportunities, and threats (SWOT analysis), (e.g., [67,68]), (Table 3).

The outcome of the integrated study of the strengths and weaknesses and opportunities and threats, as it shown in Table 3, indicates that the proposed product of geotourism encompasses geological and archaeological history together with cultural activities. In collaboration with local authorities, universities, and research centers, numerous archaeological and geological studies and projects have been carried out in the region, providing a high-level knowledge and scientific dissemination. At national and international scientific congresses, the findings of scientific studies and dissemination activities have already been presented. This geotourism product could combine "on-site" tools (totems and panels) and "digital" tools (smartphone and tablet-readable explanatory material) and could attract people of various age and digital alphabetization range. This will result in at least several thousand visitors to this unique location each year. In addition, local schools will begin to organize field trips and visits. It is worth mentioning that a huge number of students and scientists, following the initiatives of international Universities exceeding a number of one hundred, have visited the island so far.

On the other hand, an inhibitory parameter is the fact that the community residents of Syros Island are mainly engaged in tourism activities, yet they are not educated in and on earth sciences. They have limited understanding of their own geoheritage. As a consequence, the valorization of the geological heritage of the island and its exploitation 
is hindered by many adverse factors. The geological heritage promotion project on the island of Syros is barely funded by the local authorities and the universities involved. It is based mainly on regional financial support. So far, there has not been an actual marketing campaign triggered. Generally, there is still a lack of a management framework for identifying, determining and reporting whatever has to do with the geotourism product and its principles in conjunction with the surrounding areas. The high importance and future opportunities of geological and archeological heritage have not yet been understood by the locals which they still have low cognition and knowledge about its protection.

Table 3. Strengths, weaknesses, opportunities, and threats (SWOT) analysis.

\begin{tabular}{|c|c|}
\hline Strengths & Opportunities \\
\hline $\begin{array}{l}\text { - Geological and archaeological history together with } \\
\text { cultural activities } \\
\text { - } \quad \text { Of great interest to the scientific community } \\
\text { - } \quad \text { A field of special scientific interest and of natural beauty } \\
\text { - } \quad \text { Universities from around the world are visiting the island } \\
\text { to study the footprint of the subduction zone }\end{array}$ & $\begin{array}{l}\text { The number of tourists already arriving in Syros island could } \\
\text { definitely be increased } \\
\text { Network linking Syros island with the rest of Aegean islands } \\
\text { Expansion of tourism offerings } \\
\text { Increase of economic challenges } \\
\text { Competitive investments in the field of hospitality } \\
\text { New cultural events } \\
\text { New employment opportunities as local tourist guides for } \\
\text { geological-archaeological tourism } \\
\text { Creation of a geo-museum in which the regional mineralogical } \\
\text { heritage should be presented leading to the popularization of } \\
\text { related scientific knowledge } \\
\text { Economic tourism opportunities }\end{array}$ \\
\hline
\end{tabular}

\section{Weaknesses}

Threats

- $\quad$ The community residents of Syros Island are mainly engaged in tourism activities, yet they are not educated in and on earth sciences

- $\quad$ Limited knowledge of geoheritage

- $\quad$ Limited financial assistance from government agencies

- Lack of management framework

- Low cognition and knowledge about geoheritage protection
Management problems (many bodies involved) Inconsistent funding, depending on the variable funding opportunities and variable local-regional political circumstances Exposure of the geotopes to natural phenomena and the erratic invasion of tourists

Geotourism will provide good opportunities for public access. The number of tourists already arriving in Syros island could definitely be increased by developing a network linking North Syros to the rest of the island and Syros island to the rest of Cycladic and Aegean islands. This new tourism perspective could encourage the expansion of tourism offerings and the increase of economic challenges and competitive investments in the fields of hospitality (hotels, bed and breakfast, agritourism, restaurants, etc.), current and new cultural events, etc. This can also develop new employment opportunities as local tourist guides for geological-archaeological tourism. An integrated archaeological and geological wealth management strategy in relation to other natural reserves with local landscape features and local value for food and wine would directly promote and enhance economic tourism opportunities.

Moreover, the prospect of geotourism development will trigger the creation of a geomuseum in which the regional mineralogical heritage should be presented. Until today, no permanent museum dedicated to mineralogy exists in the area, but temporary exhibitions are organized, particularly in connection with annual cultural events. The geo-museum will provide all the necessary facilities for rock exhibition and popularization of related scientific knowledge. In this way, all the information will be delivered to the public.

In contrast, however, identification and evaluation of the geological heritage of the island of Syros and the construction of adequate infrastructure for the development of geotourism depend on the local municipality and is mostly funded by regional fund- 
ing. This may result in management problems (many bodies involved) and inconsistent funding, depending on the variable funding opportunities and variable local-regional political circumstances.

In addition, the exposure of the geotopes to natural phenomena and the erratic invasion of tourists, without proper guidance, constitute a great threat to the protection of the geological heritage of Syros.

\section{Discussion}

\subsection{Geotourism Potential of Syros Island}

Geotourism activities are rapidly increasing worldwide [69], and geological heritage of significant value should therefore be considered as the primary natural resource for these initiatives. The geological heritage of Syros Island, as a world-class geological heritage, will draw numerous geotourists interested in visiting unique phenomena and gaining knowledge of the Earth history and evolution. The island as a whole provides several additional possibilities that would make geotourism flows easier. The touristic infrastructure of Syros is well developed. It includes, besides the famous beaches, a lot of hotels, hostels and private accommodations, restaurants, golf courses, riding and water sport possibilities, boat and sailing tours, discotheques, as well as other leisure and sportive activities. Information sharing of geological knowledge can be of great benefit in order to achieve (1) the improvement of the attractiveness of the destination for geotourism, (2) attention to the need to preserve geological sites and the associated natural environment, and (3) the popularization of geology in general.

The geotourism potential of Syros is reinforced by the importance of tourism in general. The study area, besides the infrastructure facilities, also hosts features of significant biodiversity. These conditions make the island of Syros an attractive, nature-focused popular destination. Its current popularity among tourists would add value to the interest of geotourism, and vice versa, geotourism would strengthen tourism industry offerings.

The promotion on a global scale of the geo-cultural heritage of Syros presupposes the development of geotourism management in terms of sustainability with the parallel protection and promotion of the natural environment, i.e., the geotopes, with the establishment of an integrated management system for the future application of these areas as Geoparks, to the UNESCO World Geoparks Network. In this light, some specific actions, necessary for the inclusion of Syros geotopes in the World Geoparks, should be developed (e.g., [70,71]):

- "Development of a Management Plan and a Four-Year Action Plan" and "Detailed presentation of the Geotopes of Syros and their Evaluation",

- Creation of Interpretation and Centers of geotopes, which function as information centers, and

- Creation of outdoor geological routes and museums with placement of signs in the geotopes of interest and markings on the geotrails.

A geotope is of greater interest if combined with its anthropogenic environment [72]. A geological monument must be related to the surrounding area and the cultural heritage of the surrounding area. This direction may be assisted by the "Geotourist Guides" that describe various actions that can be carried out in a place depending on the interest, time and opportunity of each visitor [73]. In these guides, it is advisable to provide information about the cultural monuments and to make a direct connection of the geological with the cultural element, but also with the daily life of the inhabitants.

\subsection{The Archaeological and Cultural Framework of Syros Island}

The promotion and establishment of a geotope as a geotourism product can be further enhanced by its coexistence and combination with various tourism activities as well as other types of tourism (cultural tourism, ecotourism, gastrotourism etc.). One of the most popular forms of tourism, usually combined with geotourism is the archaeotourism [74-76].

Syros Island is well known for it is also an island of great archaeological wealth worth discovering [77-80]. The most important and famous archaeological sites of Syros are 
concentrated in the northern part of the island (Figure 8): Chalandriani with the Early Cycladic cemetery and the more than 600 excavated tombs, Kastri which is acropolis and settlement of the same period, the bay of Grammata with the inscriptions engraved on the rocks of the Hellenistic and Byzantine period [81], the cave of Ferekidis with traces of human presence during the Archaic period.

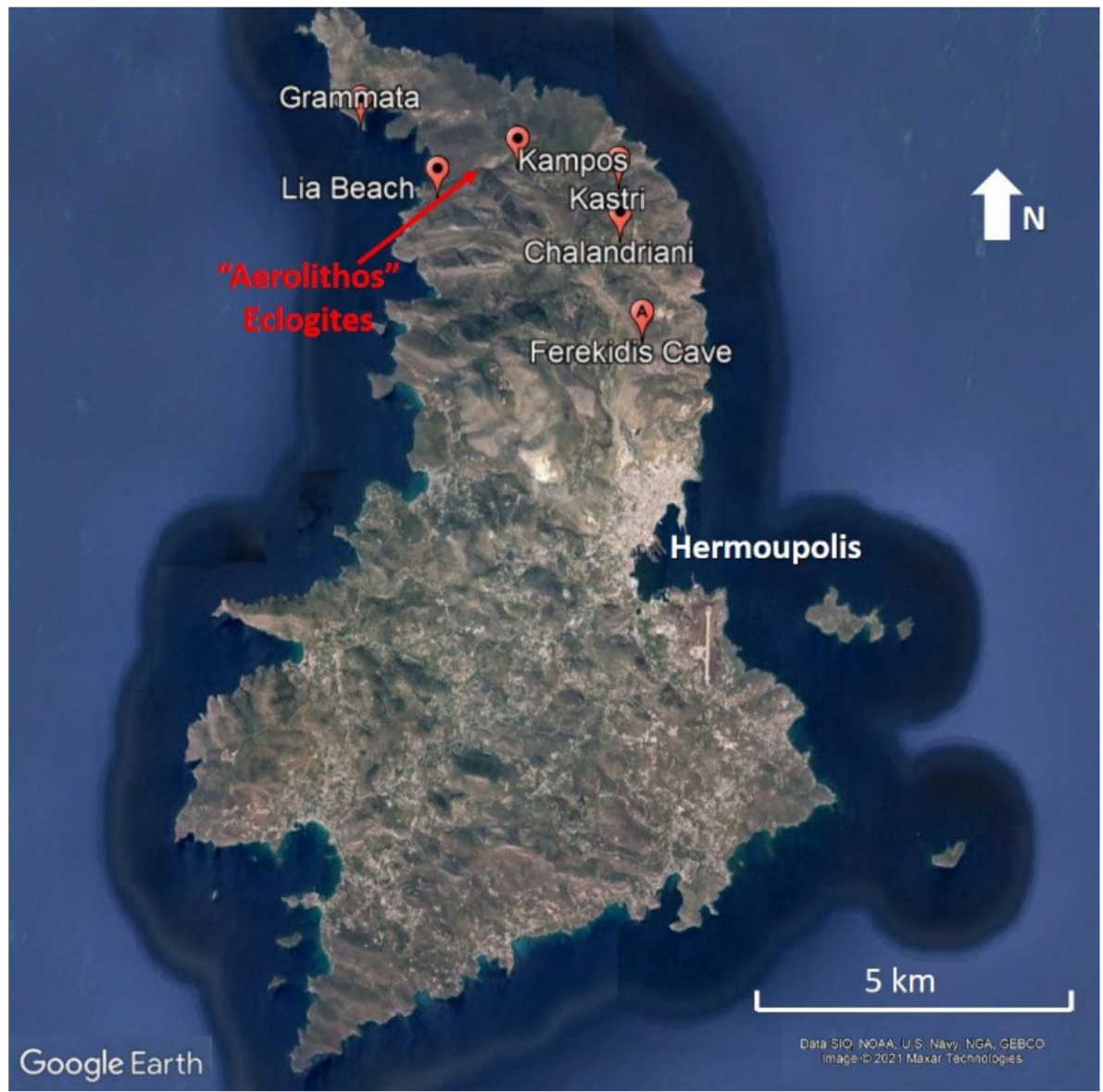

Figure 8. Satellite photo of Syros island, indicating the sites of archaeological interest surrounding the "Aerolithos" Eclogite geosite.

The cultural attractions of Syros keep the visitor's interest undiminished at every step on the island. The cities and villages are themselves the most important cultural attractions. Hermoupolis, the capital of Syros and the Cyclades, a city built in the 19th century has a variety of buildings of the time, with neoclassical style and influences from romantic architecture [82]. Among the cultural attractions of Syros that can be seen in the city are the City Hall, the Cultural Center, Miaouli Square, the church of Agios Nikolaos, the port and the Municipal Theater "Apollo", a work of the great German architect Ernst Ziller. Ano Syros, the old town of the island stands on the spot since the Middle Ages and is one of the most important cultural attractions of Syros. The medieval gates lead to the narrow streets of the settlement, with the countless churches, most of them catholic. The other villages of the island, such as Poseidonia, Finikas, but also the small villages of Apano Meria, host many of the sights and cultural events of Syros, which are worth seeing. Events such as the International Film Festival, or exhibitions held at the Ermoupolis Industrial Museum and the Maritime Museum in Kini, the Accordion Festival and the AnimaSyros International Animation Festival take place every year on the island. Concerts, theatrical performances, art exhibitions and festivals give the visitor a multicultural experience in the field of art and culture. 


\subsection{Institutional Geoheritage Framework}

Syros, and particularly northern Syros, is an important habitat of great archaeological interest and today is protected by Greek law, as an area of special natural beauty. It is also included in the European network of protected areas NATURA 2000, which is the main national means for the purpose of Directive 92/43/EEC of the European Council "for the conservation of natural habitats and wild fauna and flora" which are significant at European level (the aforementioned Directive was incorporated into a Joint Ministerial Decision 33318/3028 / 1998 1289/V/28-12-98-Government Gazette).

Nowadays, there is a government initiative aiming to protect sites that are considered very important in terms of their geodiversity, particularly if they are listed as geological heritage [75-85]. The development of a geosite inventory should be the first step in any strategy for the conservation of geological heritage. The implementation of preservation and evaluation without a complete inventory of geotopes is an unacceptable starting point for any geoconservation project [86]. Establishing a protected area is a long and complicated bureaucratic process in several countries. This initiative must therefore be applied only to those geotopes which stand out because of their scientific, academic, and tourism values. To assess this importance, a consistent national inventory is crucial. Following the creation of an inventory of geosites, the basic steps in the geo-conservation strategy must be to characterize them by assessing their relevance, protecting them in accordance with the national legal framework, preserving, interpreting and monitoring them.

Although well-known and identified, the eclogites and the other important and rare HP-LT rocks and geological structures on Syros Island are not officially protected. All related international conventions have been signed by Greece, and the institutional structure established guarantees the possibility of preserving and enhancing even individual geotopes surrounded by incompatible uses of the mild and sustainable development model (i.e., urban environment, industrial park, etc.). In particular, the protection structure given by Law 1650/86 for the category "natural formations-landscapes-landscapes" components' has been substantially improved by the new Biodiversity Law 3937/2011. This legislation specifically provides for the preservation of functional parts of nature or of human creations which are of particular scientific, ecological, geological, geomorphological, or aesthetic significance and thus contribute to the conservation of natural processes and to the protection of natural resources.

\subsection{Future Perspectives}

Syros has a strategic advantage in the field of geotourism, as the island is considered one of the most representative location of blueschists, jadeitites, and eclogites in the world. The whole island is a geological museum that is hard to find. For these reasons, Syros island is characterized by geological heritage of global interest. Given the importance of the local natural and geological environment to the active development of tourism, it is proposed that this locality should be included in a future Geopark. The profit from the promotion and utilization of its geological wealth with the aim of its integration in the world environment of the Geoparks, is obvious. In general, it is estimated that the benefit to the island as a whole will be particularly significant.

The long-term objective is to formally establish a geopark on the island of Syros which would claim the status of a UNESCO Global Geopark. The key requirements set for Global Geoparks, such as the presence of outstanding geo-heritage and local community engagement, are or may be met in the near future. Achieving the UNESCO Global Geopark status would provide valuable international recognition, thereby helping to strengthen the residential and tourist appeal of the region, a lever for local economic development that will protect these assets. The designation of Syros island as a geological monument of global importance and its integration in the Global Geoparks will result in the attraction of tourism on the island, with direct positive consequences for local development, in terms of competitiveness, employment growth, enhancing living standards and social welfare. 
The ambition of the local authorities is to develop a responsible geotourism and actions concerning geo-education which are going to contribute to the economic development of the Cyclades islands. The development of geotourism on the island of Syros through the use of geological morphology, with the principles of sustainable development through tourism and educational activities will contribute to the economic development of the wider region. The geotourism growth is intertwined and complementary with the operation of the geopark as well as with the establishment of a geological exhibition (geo-museum) where the geological history of Syros will be presented.

\subsection{Recommendations}

In order to achieve the goals mentioned above, a lot of related work has to be done including:

1. Geosite inventory: An inventory comprising the various geosites of Syros island, must be created and discussed. Regarding the geological information and the interests of geodiffusion, we plan to show, describe, and explain the preserved evidence of processes active in deep levels of orogens, and then explain the birth and development of an orogeny. Geo-diffusion activities undertaken encompass concepts and configuration of geological trails along the most impressive and indicative cross sections, most of which are dedicated to displaying characteristics of these processes.

2. Capacity building: Geological experts obtain information through literature collection and on-the-spot investigations, and then translate scientific data into popular materials that the public can understand. Through continuous and hierarchical training including the seed narrator training, environmental education for students of primary and high school, etc., to learn about the land where you live, and to introduce the story of their hometown;

3. Networking activities: In order to continuously improve the ability of community residents to promote the geopark, to share the experience promoted by domestic and foreign geoparks. Networking activities involve the organization of conferences, workshops, training courses, field studies, production, and presentation of local geoproducts, among others. Moreover, through interviews with community cadres and the public, surveys and inventory of resources will be conducted with the community to understand the geology, landscape, human history, ecology, and agricultural specialties that they own, as applicable resources for the geopark;

4. Development and production of promotional material: To promote the geopark, increase the elements and characteristics of the territory, scholars and community residents jointly carry out the LOGO design of the Syros Geopark, and make folding, postcards, bags, books, brochures, among others.

There are many prospects for the future, including improvement of sustainable development plans, continuing to build capacity for local communities, seeking support from local governments, providing guided tours and developing geo-products.

Following these first moves, further actions will involve the combination of scientific processes and methodologies, along with geosite-based items, as well as museum collections, scientific displays and nature trails.

In addition, multimedia and virtual reality approaches are designed to visualize and communicate this remarkable natural heritage as widely as possible to an audience. Last but not least, the creation of geodiversity action plans, including educational impacts and promotion of a "geodiversity economy" are further steps in the activity.

\section{Conclusions}

Syros is a chest full of fascinating, rare, and well-exposed geological and archaeological features, something that attracts geologists and archaeologists from all over the world every year. The geological heritage of Syros represents a wide spectrum of unique phenomena. Syros Island is a world-class reference for the preservation of HP-LT metamorphic rocks such as eclogite and glaucophane schist. Together with the development of the Cycladic 
culture, all the treasures are locked up in the rocks of Syros waiting to be unlocked. For this to happen, a Geopark must be created on Syros aiming to bring both the Earth history and Ancient Greek Scientific Tradition into worldwide awareness and appreciation and make Syros a unique cultural and scientific park for the entire world to admire.

In both contexts-geology and archaeology-rocks serve as cultural archives. The Syros Geopark will aim to highlight and protect the heritage treasures

- of fundamental processes operating in an oceanic subduction zone

- of the geological evolution of Syros over some 60 million years

- of human culture and evolution on Syros over 8000 years.

The links between the natural geological heritage in Syros and its human history must be exposed to the public, and the cultural treasures as well as particularly valuable geological sites must be protected.

Author Contributions: Conceptualization, H.D.; methodology, H.D.; investigation, H.D., T.T., M.P., G.P., C.P., and A.M.; resources, M.P., C.P., and A.M.; writing-original draft preparation, H.D.; writing - review and editing, H.D., T.T., and A.M.; supervision, H.D. and A.M. All authors have read and agreed to the published version of the manuscript.

Funding: The research paper was partially funded by the Special Account for Research Grants (S.A.R.G.) of the National and Kapodistrian University of Athens (Greece).

Institutional Review Board Statement: Not applicable.

Informed Consent Statement: Not applicable.

Data Availability Statement: The data presented in this study are available on request from the corresponding author.

Acknowledgments: The authors gratefully thank the journal editor and the three reviewers for their thorough consideration of this paper. They also express their sincere thanks to Martin Engi for his kind and very professional advices as well as his continuous efforts for the promotion and development of the Syros Geological Museum.

Conflicts of Interest: The authors declare no conflict of interest.

\section{References}

1. Goudie, A.G. Encyclopedia of Geomorphology; Routledge: London, UK, 2004.

2. Zouros, N.; Valiakos, I. Geoparks Management and Assessment. Bull. Geol. Soc. Greece 2017, 43, 965-977. [CrossRef]

3. Fassoulas, C.; Zouros, N. Evaluating the Influence of Greek Geoparks to The Local Communities. Bull. Geol. Soc. Greece 2017, $43,896$. [CrossRef]

4. Stoffelen, A.; Groote, P.; Meijles, E.; Weitkamp, G. Geoparks and territorial identity: A study of the spatial affinity of inhabitants with UNESCO Geopark De Hondsrug, The Netherlands. Appl. Geogr. 2019, 106, 1-10. [CrossRef]

5. Eder, F.W. Geoparks-Geological attractions: A tool for public education, recreation and sustainable economic development. Episodes 2004, 27, 162-164. [CrossRef] [PubMed]

6. Zouros, N. The European Geoparks Network-Geological heritage protection and local development. Episodes 2004, $27,165-171$. [CrossRef]

7. Fermeli, G. Geological-Geomorphological Heritage, Theory and Practice, Educational Tool for the Teaching and Assessment of GeologyGeography and Environmental Education; Post-Doctoral Research; University of Athens: Athens, Greece, 2004 ; p. 440.

8. Theodosiou, E.; Fermeli, G.; Koutsouveli, A. Our Geological Heritage; Kaleidoskopion: Athens, Greece, 2006.

9. Fassoulas, C.; Paragamian, K.; Iliopoulos, G. Identification and assessment of Cretan geotopes. Bull. Geol. Soc. Greece 2007, 40, 1780-1795. [CrossRef]

10. Psychogiou, M.; Georgiou, K.; Antonarakou, A.; Drinia, H. A field trip enhanced with ARTutor, an augmented reality educational platform. Eur. Geol. Eur. Geol. 2019. Available online: https://eurogeologists.eu/psychogiou-a-field-trip-enhanced-with-artutoran-augmented-reality-educational-platform/ (accessed on 22 December 2020).

11. Mariolakos, I. The Geo-Environmental Dimension of Greek Mythology. Bull Hell Geol Soc. 2002, 26, 2065-2086.

12. Karamani, P.; Drinia, H.; Panagiaris, G. Geotourism as a tool for the protection and promotion of the Cave of Galaxidi. In Proceedings of the 15th International Congress of the Geological Society of Greece Athens, Athens, Greece, $22-24$ May 2019.

13. Kapsimalis, V.; Pavlopoulos, K.; Panagiotopoulos, I.; Drakopoulou, P.; Vandarakis, D.; Sakelariou, D.; Anagnostou, C. Geoarchaeological challenges in the Cyclades continental shelf (Aegean Sea). Z. Geomorphol. Suppl. Issues 2009, 53, 169-190. [CrossRef]

14. Skentos, A. Geotopes of Greece. Master's Thesis, University of Athens, Athens, Greece, 2012. 
15. Cliff, R.A.; Bond, C.E.; Butler, R.W.H.; Dixon, J.E. Geochronological challenges posed by continuously developing tectonometamorphic systems: Insights from Rb-Sr mica ages from the Cycladic Blueschist Belt, Syros (Greece). J. Metamorph. Geol. 2016, 35, 197-211. [CrossRef]

16. Keiter, M.; Ballhaus, C.; Tomaschek, F. A new geological map of the Island of Syros (Aegean Sea, Greece): Implications for lithostratigraphy and structural history of the Cycladic Blueschist Unit. Geol. Soc. Am. Spec. Pap. 2011. [CrossRef]

17. Keiter, M.; Piepjohn, K.; Ballhaus, C.; Lagos, M.; Bode, M. Structural development of high-pressure metamorphic rocks on Syros island (Cyclades, Greece). J. Struct. Geol. 2004, 26, 1433-1445. [CrossRef]

18. Lagos, M.; Scherer, E.E.; Tomaschek, F.; Münker, C.; Keiter, M.; Berndt, J.; Ballhaus, C. High precision Lu-Hf geochronology of Eocene eclogite-facies rocks from Syros, Cyclades, Greece. Chem. Geol. 2007, 243, 16-35. [CrossRef]

19. Laurent, V.; Jolivet, L.; Roche, V.; Augier, R.; Scaillet, S.; Cardello, G.L. Strain localization in a fossilized subduction channel: Insights from the Cycladic Blueschist Unit (Syros, Greece). Tectonophysics 2016, 672-673, 150-169. [CrossRef]

20. Laurent, V.; Huet, B.; Labrousse, L.; Jolivet, L.; Monié, P.; Augier, R. Extraneous argon in high-pressure metamorphic rocks: Distribution, origin and transport in the Cycladic Blueschist Unit (Greece). Lithos 2017, 272-273, 315-335. [CrossRef]

21. Lister, G.S.; Forster, M. White mica $40 \mathrm{Ar} / 39 \mathrm{Ar}$ age spectra and the timing of multiple episodes of high-P metamorphic mineral growth in the Cycladic eclogite-blueschist belt, Syros, Aegean Sea, Greece. J. Metamorph. Geol. 2016, 34, 401-421. [CrossRef]

22. Philippon, M.; Brun, J.-P.; Gueydan, F. Tectonics of the Syros blueschists (Cyclades, Greece): From subduction to Aegean extension. Tectonics 2011, 30. [CrossRef]

23. Schumacher, J.C.; Brady, J.B.; Cheney, J.T.; Tonnsen, R.R. Glaucophane-bearing Marbles on Syros, Greece. J. Pet. 2008, 49, 1667-1686. [CrossRef]

24. Soukis, K.; Stockli, D.F. Structural and thermochronometric evidence for multi-stage exhumation of southern Syros, Cycladic islands, Greece. Tectonophysics 2013, 595-596, 148-164. [CrossRef]

25. Tomaschek, F.; Kennedy, A.K.; Villa, I.M.; Lagos, M.; Ballhaus, C. Zircons from Syros, Cyclades, Greece-Recrystallization and Mobilization of Zircon During High-Pressure Metamorphism. J. Pet. 2003, 44, 1977-2002. [CrossRef]

26. Trotet, F.; Jolivet, L.; Vidal, O. Tectono-metamorphic evolution of Syros and Sifnos islands (Cyclades, Greece). Tectonophysics 2001, 338, 179-206. [CrossRef]

27. Trotet, F.; Vidal, O.; Jolivet, L. Exhumation of Syros and Sifnos metamorphic rocks (Cyclades, Greece). New constraints on the P-T paths. Eur. J. Miner. 2001, 13, 901-920. [CrossRef]

28. Jolivet, L.; Brun, J.-P. Cenozoic geodynamic evolution of the Aegean. Acta Diabetol. 2008, 99, 109-138. [CrossRef]

29. Ring, U.; Glodny, J.; Will, T.; Thomson, S.N. The Hellenic subduction system: High pressure metamorphism, exhumation, normal faulting and large-scale extension. Ann. Rev. Earth Planet. Sci. 2010, 38, 45-76. [CrossRef]

30. Stampfli, G.M. Tethyan Oceans. In Tectonics and Magmatism in Turkey and Surrounding Area; Bozkurt, E., Winchester, J.A., Piper, J.D.A., Eds.; Geological Society of London: London, UK, 2000; Volume 173, pp. 163-185.

31. Malinverno, A.; Ryan, W.B.F. Extension in the Tyrrhenian Sea and shortening in the Apennines as result of arc migration driven by sinking of the lithosphere. Tectonics 1986, 5, 227-245. [CrossRef]

32. Jolivet, L.; Faccenna, C. Meditterranean extension and the Africa-Eurasia collision. Tectonics 2000, 19, 1095-1106. [CrossRef]

33. Jolivet, L.; Augier, R.; Faccenna, C.; Negro, F.; Rimmele, G.; Agard, P.; Robin, C.; Rossetti, F.; Blanc, A.C. Subduction, convergence and the mode of backarc extension in the Mediterranean region. BSGF Earth Sci. Bull. 2008, 179, 525-550. [CrossRef]

34. Lister, G.S.; Banga, G.; Feenstra, A. Metamorphic core complexes of Cordilleran type in the Cyclades, Aegean Sea, Greece. Geology 1984, 12, 221-225. [CrossRef]

35. Olivet, L.; Faccenna, C.; Huet, B.; Labrousse, L.; Le Pourhiet, L.; Lacombe, O.; Lecomte, E.; Burov, E.; Denèle, Y.; Brun, J.-P.; et al. Aegean tectonics: Strain localisation, slab tearing and trench retreat. Tectonophysics 2013, 597-598, 1-33. [CrossRef]

36. Durr, S.; Altherr, R.; Keller, J.; Okrusch, M.; Seide, E. The Median Aegean Crystalline Belt: Stratigraphy, Structure, Metamorphism, Magmatism; Cloos, H., Roeder, D., Schmidt, K., Eds.; Alps, Apennines, Hellenides, Schweizerbart: Stuttgart, Germany, 1978; pp. 455-477.

37. Schliestedt, M.; Altherr, R.; Matthews, A. Evolution of the Cycladic Crystalline Complex: Petrology, Isotope Geochemistry and Geochronolgy. In Chemical Transport in Metasomatic Processes; Springer International Publishing: Berlin/Heidelberg, Germany, 1987; pp. 389-428.

38. Okrusch, M.; Bröcker, M. Eclogites associated with high-grade blueschists in the Cyclades archipelago, Greece: A review. Eur. J. Miner. 1990, 2, 451-478. [CrossRef]

39. Bonneau, M. Correlation of the Hellenide nappes in the south-east Aegean and their tectonic reconstruction. Geol. Soc. London, Spec. Publ. 1984, 17, 517-527. [CrossRef]

40. Okrusch, M.; Seidel, E.; Kreuzer, H.; Harre, W. Jurassic age of metamorphism at the base of the Brezovica peridotite (Yugoslavia). Earth Planet. Sci. Lett. 1978, 39, 291-297. [CrossRef]

41. Matthews, A.; Schliestedt, M. Evolution of the blueschist and greenschist facies rocks of Sifnos, Cyclades, Greece. Contrib. Miner. Pet. 1984, 88, 150-163. [CrossRef]

42. Bröcker, M.; Kreuzer, H.; Matthews, A.; Okrusch, M. 40Ar/39Ar and oxygen isotope studies of polymetamorphism from Tinos Island, Cycladic blueschist belt, Greece. J. Metamorph. Geol. 1993, 11, 223-240. [CrossRef]

43. Brocker, M.; Baldwin, S.L.; Arkudas, R. The geological significance of $40 \mathrm{Ar} / 39 \mathrm{Ar}$ and Rb-Sr white mica ages from Syros and Sifnos, Greece: A record of continuous (re)crystallization during exhumation? J. Metamorph. Geol. 2013, 31, 629-646. [CrossRef] 
44. Ring, U.; Thomson, S.N.; Bröcker, M. Fast extension but little exhumation: The Vari detachment in the Cyclades, Greece. Geol. Mag. 2003, 140, 245-252. [CrossRef]

45. Kirchner, K.; Kubalíková, L. Relief assessment methodology with respect to geoheritage based on example of the Deblínská vrchovina highland. In Proceedings of the Public Recreation and Landscape Protection-With Man Hand in Hand? Brno, Czech Republic, 1-3 May 2013; Available online: http:/ / www.utok.cz/sites/default/files/data/USERS/u24/Kirchner.pdf (accessed on 22 December 2020).

46. Kubalíková, L.; Kirchner, K. Geosite and Geomorphosite Assessment as a Tool for Geoconservation and Geotourism Purposes: A Case Study from Vizovická vrchovina Highland (Eastern Part of the Czech Republic). Geoheritage 2016, 8, 5-14. [CrossRef]

47. Nazaruddin, D.A. Systematic Studies of Geoheritage in Jeli District, Kelantan, Malaysia. Geoheritage 2017, 9, 19-33. [CrossRef]

48. Ates, H.C.; Ateş, Y. Geotourism and Rural Tourism Synergy for Sustainable Development—Marçik Valley Case-Tunceli, Turkey. Geoheritage 2018, 11, 207-215. [CrossRef]

49. Voudouris, P.; Mavrogonatos, C.; Graham, I.; Giuliani, G.; Tarantola, A.; Melfos, V.; Karampelas, S.; Katerinopoulos, A.; Magganas, A. Gemstones of Greece: Geology and Crystallizing Environments. Minerals 2019, 9, 461. [CrossRef]

50. Katerinopoulou, A.; Katerinopoulos, A.; Bieniok, A.; Knop, E.; Magganas, A.; Amthauer, G. Crystal chemistry, structure analyses and phase transition experiment on an omphacite from eclogitic metagabbro from Syros island, Greece. Miner. Pet. 2007, 91, 117-128. [CrossRef]

51. Hausmann, H. Beiträge zur Oryktographie von Syra. J. Praktische Chemie 1845, 34, 238-241. [CrossRef]

52. Fassoulas, C.; Mouriki, D.; Dimitriou-Nikolakis, P.; Iliopoulos, G. Quantitative Assessment of Geotopes as an Effective Tool for Geoheritage Management. Geoheritage 2012, 4, 177-193. [CrossRef]

53. Archontikis, O.A. Revealing the Geoheritage of Attica and Eastern Peloponnes through Geotouristic Routes. Master's Thesis, Department of Geology and Geoenvironment, National and Kapodistrian University of Athens, Athens, Greece, 2017.

54. Cendrero, A. El Patrimonio Geológico. Ideas para su Protección, Conservación y Utilización. In El Patrimonio Geológico: Bases para su Valoración, Protección, Conservación y Utilización; Serie Monografías del Ministerio de Obras Públicas, Transportes y Medio Ambiente; Ministerio de Obras Públicas, Transportes y Medio Ambiente, Dirección General de Información y Evaluación Ambiental: Madrid, Spain, 1996; pp. 17-27.

55. Cendrero, A. Propuestas Sobre Criterios para la Clasificación y Catalogación del Patrimonio Geológico. In El Patrimonio Geológico: Bases para su Valoración, Protección, Conservación y Utilización; Serie Monografías del Ministerio de Obras Públicas, Transportes y Medio Ambiente; Ministerio de Obras Públicas, Transportes y Medio Ambiente, Dirección General de Información y Evaluación Ambiental: Madrid, Spain, 1996; pp. 29-38.

56. Coratza, P.; Giusti, C. Methodological proposal for the assessment of the scientific quality of geomorphosites. Il Quaternario 2005, 18, 307-313.

57. Pralong, J.P.; Reynard, E. A proposal for the classification of geomorphological sites depending on their tourist value. Quaternario 2005, 18, 315-321.

58. Pereira, P.; Pereira, D.; Alves, M.I.C. Geomorphosite assessment in Montesinho Natural Park (Portugal). Geogr. Helv. 2007, 62, 159-168. [CrossRef]

59. Reynard, E.; Fontana, G.; Kozlik, L.; Scapozza, C. A method for assessing "scientific" and "adicional values" of geomorphosites. Geogr. Helv. 2007, 62, 148-158. [CrossRef]

60. Bruschi, V.M.; Cendrero, A. Direct and Parametric Methods for the Assessment of Geosites and Geomorphosites. In Geomorphosites; Reynard, E., Coratza, P., Regolini-Bissig, G., Eds.; Verlag Dr. Friedrich Pfeil: München, Germany, 2009; pp. 73-88.

61. Reynard, E. The Assessment of Geomorphosites. In Geomorphosites; Reynard, E., Coratza, P., Regolini Bissig, G., Eds.; Verlag Dr. Friedrich Pfeil: Munchen, Germany, 2009; pp. 63-71.

62. Pereira, P.; Pereira, D. Methodological guidelines for geomorphosite assessment. Géomorphologie: Relief, processus. Environnement 2010, 16, 215-222. [CrossRef]

63. Bruschi, V.M.; Cendrero, A.; Albertos, J.A.C. A statistical approach to the validation and optimisation of geoheritage assessment procedures. Geoheritage 2011, 3, 131-149. [CrossRef]

64. Pereira, P.; Pereira, D.I. Assessment of geosites tourism value in geoparks: The example of Arouca Geopark (Portugal). In Proceedings of the 11th European Geoparks Conference, Arouca, Portugal, 19-21 September 2012; pp. 231-232.

65. Bollati, I.; Smiraglia, C.; Pelfini, M. Assessment and selection of geomorphosites and trails in the Miage Glacier area (Western Italian Alps). Environ. Manag. 2013, 51, 951-967. [CrossRef]

66. Dowling, R.K. Global Geotourism-An Emerging Form of Sustainable Tourism. Czech J. Tour. 2013, 2, 59-79. [CrossRef]

67. Mero, P.C.; Franco, G.H.; Briones, J.; Caldevilla, P.; Domínguez-Cuesta, M.J.; Berrezueta, E. Geotourism and Local Development Based on Geological and Mining Sites Utilization, Zaruma-Portovelo, Ecuador. Geosciences 2018, 8, 205. [CrossRef]

68. Piacentini, T.; Miccadei, E.; Berardini, G.; Aratari, L.; De Ioris, A.; Calista, M.; Carabella, C.; D’'Arielli, R.; Mancinelli, V.; Paglia, G.; et al. Geological tourist mapping of the Mount Serrone fault Geosite (Gioia dei Marsi, Central Apennines, Italy). J. Maps 2019, 15, 298-309. [CrossRef]

69. Newsome, D.; Dowling, R. Geoheritage and Geotourism. Geoheritage 2018, 305-321. [CrossRef]

70. Brilha, J. Geoheritage and Geoparks. Geoheritage 2018, 323-335. [CrossRef]

71. Justice, S.C. UNESCO Global Geoparks, Geotourism and Communication of the Earth Sciences: A Case Study in the Chablais UNESCO Global Geopark, France. Geosciences 2018, 8, 149. [CrossRef] 
72. Radwanek-Bak, B. Geodiversity assessment of the rio colca valley and its surrounding (Southern peru) in the context of future geopark. In Proceedings of the International Multidisciplinary Scientific GeoConference Surveying Geology and Mining Ecology Management (SGEM), Albena, Bulgaria, 17-26 June 2014. [CrossRef]

73. Pál, M.; Albert, G. Digital cartography for geoheritage: Turning an analogue geotourist map into digital. Proc. Int. Cartogr. Assoc. 2019, 2, 96. [CrossRef]

74. Rapidah, M.S.; Mohamed, K.R.; Ali, C.A.; Leman, M.S.; Saidin, M. A geotouristic itinerary: A proposal for geotourism and archaeotourism development of Lenggong valley, Perak, Malaysia. Geoj. Tour. Geosites. 2018, 22, 597. [CrossRef]

75. Shrivastava, S. Archaeotourism: An Approach to Heritage Conservation and Area Development. Glob. J. Eng. Sci. Soc. Sci. Stud. 2015, 1, 31-42.

76. Baram, U. Tourism and Archaeology. In Encyclopedia of Archaeology; Academic Press: Cambridge, MA, USA, 2008. [CrossRef]

77. Broodbank, C. The Longboat and Society in the Cyclades in the Keros-Syros Culture. Am. J. Archaeol. 1989, 93, 319. [CrossRef]

78. Hekman, J.J. The Early Bronze Age Cemetery at Chalandriani on Syros (Cyclades, Greece). Ph.D. Thesis, University of Groningen, Groningen, The Netherlands, 2003.

79. Marthari, M. Syros: Chalandriani and Kastri: From the Investigation and Protection to the Presentation of an Archaeological Site. Ministry of Culture. 1998. Available online: https://www.academia.edu/26021765/Syros_Chalandriani_Kastri_From_the_ Investigation_and_Protection_to_the_Presentation_of_an_Archaeological_Site (accessed on 20 February 2021).

80. Stos-Gale, Z.; Gale, N.; Gilmore, G. Early Bronze Age Trojan Metal Sources and Anatolians in the Cyclades. Oxf. J. Archaeol. 1984, 3, 23-44. [CrossRef]

81. Von Gaertringen, F.H. Inscriptiones Graecae, XII 5. Inscriptiones Cycladum, Reimer-Berlin 1903-1909. Available online: https: //www.atticinscriptions.com/browse/bysource/IGXII5/ (accessed on 20 February 2021).

82. Stratton, M.; Trinder, B. Hermoupolis: The archaeology of a Mediterranean industrial city. Ind. Archaeol. Rev. 1994, 16, 184-195. [CrossRef]

83. Brilha, J.B. Inventory and Quantitative Assessment of Geosites and Geodiversity Sites: A Review. Geoheritage 2016, 8, 119-134. [CrossRef]

84. Dowling, J.R. Geotourism's global growth. Geoheritage 2011, 3, 1-13. [CrossRef]

85. Gray, M. Geodiversity: Valuing and Conserving Abiotic Nature; Wiley: Chichester, UK, 2004; p. 448.

86. De Lima, F.F.; Brilha, J.B.; Salamuni, E. Inventorying Geological Heritage in Large Territories: A Methodological Proposal Applied to Brazil. Geoheritage 2010, 2, 91-99. [CrossRef] 